\title{
GROUNDWATER PROSPECTING USING THE DIPOLE- DIPOLE CONFIGURATION FOR VERTICAL ELECTRICAL SOUNDING: PREDICTION OF MAJOR AQUIFER DEPTH IN THE TOLON-KUMBUNGU DISTRICT OF NORTHERN GHANA
}

\author{
A. N. Mumuni ${ }^{*}$ and J. S. Bayor ${ }^{2}$ \\ ${ }^{1}$ Department of Biomedical Laboratory Sciences, School of Allied Health Sciences, University for \\ Development Studies, Tamale, Ghana \\ Corresponding author: "mnashiru@uds.edu.gh \\ ${ }^{2}$ Department of Applied Physics, Faculty of Applied Sciences, University for Development Studies, \\ Navrongo \\ bayorjude@yahoo.com
}

\begin{abstract}
A geophysical investigation in groundwater prospecting, using the vertical electrical sounding (VES) method in resistivity surveying, was undertaken in the Tolon-Kumbungu district of Northern Ghana. The aim was to evaluate the effectiveness of the VES technique as a low-cost groundwater exploration method. Using the dipole-dipole VES technique, fracture zones that held good prospects for groundwater location were prospectively identified at 15 sites in the Gbullung and Wayamba communities of the district. In addition, retrospective VES data for 6 sites were obtained from previous studies. Geophysical VES data and available drill logs for 3 sites in the prospective study and all 6 sites in the retrospective study (a total of 9 sites) were then evaluated by the VES log-log graph interpretation method to establish a correlation with the groundwater characteristics of the study area. The analyses of the VES curves indicated the presence of anomalous fracture zones occurring within hard sandstone formations that had high groundwater potential. Weathered zones or fresh rock aquifers however did not show potential for groundwater. The dominant formations in the area were found to be thin-bedded sequences of sandstone, mudstone, shale, siltstone and their intercalations. Groundwater was confined to between the depths of $25.0 \mathrm{~m}$ and $40.0 \mathrm{~m}$, with major aquifers occurring approximately between the depths of $34.0 \mathrm{~m}$ and $45.0 \mathrm{~m}$. These predictions were confirmed by the available drill logs. Using the VES curve interpretation as a means of selecting promising water-bearing sites, 8 out of the 9 sites drilled were successful wells, recording water yields ranging from $14 \mathrm{~L} / \mathrm{min}$ to 250 L/min, with an average yield of $87.3 \mathrm{~L} / \mathrm{min}$. The study thus showed that the dipole-dipole VES technique in groundwater prospecting is effective for the geology of the study area.
\end{abstract}

Keywords: Tolon-Kumbungu, vertical electrical sounding, aquifer, groundwater, apparent resistivity

INTRODUCTION

Groundwater is of major importance to civiliza- tion because it is the largest reserve of drinkable water in regions where humans can live. 


\section{Mumuni and Bayor}

Groundwater may appear either at the ground surface in the form of springs, or it may be trapped in wells. During dry periods, it can also sustain the flow of surface water. Groundwater is often preferable because it tends to be less contaminated by wastes and organisms (Falkenmark and Rockström, 1993; Wicanderand Monroe, 1995), and so consumption of groundwater could mean being free from water related diseases such as cholera, guinea worm, river blindness, and typhoid.

It is estimated that 780 million people, mostly living in the rural areas of the developing world, do not have access to potable water of adequate quality and quantity (WHO/UNICEF, 2012). There is therefore the growing consensus that these numbers can only be reduced significantly through approaches that are low cost and that involve the affected communities in the planning, financing and maintenance of such approaches (UNDP, 1994; World bank, 1993). Scarcity of drinkable water in this case is partly due to hydroclimatological and other physical circumstances; but more importantly, the situation is associated with the capacity to exploit various drinkable water sources, which include the exploration and extraction of groundwater (Falkenmark and Rockström, 1993).

Where funds are limited, hand-pump equipped wells appear to be the most suitable decentralized and low-cost approach to providing drinking water in rural areas (UNDP, 1994). However, one aspect of low-cost community water supply that has received less attention is groundwater exploration or well siting. Meanwhile, a properly sited well can significantly increase water supply at a low cost.

In fact, communities in the Tolon-Kumbungu district had in the past sited and constructed hand-dug wells by indigenous methods (TolonKumbungu District Assembly, 2006). Water from these wells was complemented by other sources such as ponds, dugouts and streams. The wells were usually dug through overburden and weathered rock material and were typically only up to $8 \mathrm{~m}$ deep. When these wells were not yielding any water during the dry season, they were abandoned and other sources of wa- ter were resorted to until the aquifers were recharged in the rainy season (Bayor, 2004; Dapaah-Siakwan and Gyau-Boakye, 1999).

A number of geophysical techniques are available for locating groundwater (MacDonald, Davies and Peart, 2001). The Frequency domain electromagnetic (FEM) method measures apparent terrain electrical conductivity at a maximum depth of $50 \mathrm{~m}$ below the ground surface. It is a quick and easy-to-implement method for determining changes in thickness of weathered zones or alluvium. Interpretation of FEM data however requires careful geological control. The Transient electromagnetic (TEM) method measures apparent electrical resistance of the ground at a maximum depth of $100 \mathrm{~m}$. TEM is better at locating targets through conductive overburden than FEM; it also has a better depth of penetration, but is expensive and difficult to operate. Ground penetrating radar (GPR) measures reflections from boundaries between bodies (10 $\mathrm{m}$ below the ground) of different dielectric constant. GPR is an accurate method for determining the thickness of sand and gravel, but cannot penetrate clay. Seismic refraction (SR) measures P-wave velocity through the ground to a maximum depth of $100 \mathrm{~m}$. It can locate fracture zones in basement rock and also thickness of drift deposits. It is however not suitable for measuring variations in composition of drift, and is fairly slow and difficult to interpret. The Magnetic survey (MS) technique measures intensity (and sometimes direction) of the earth's magnetic field at a maximum depth of $30 \mathrm{~m}$. It can locate magnetic bodies such as dykes or sills, but is susceptible to noise from any metallic object or power cables. The Very Low Frequency (VLF) technique measures secondary magnetic fields induced in the ground by military communications transmitters. It can locate vertical fracture zones and dykes within basement rocks or major aquifers $40 \mathrm{~m}$ below the ground surface.

The Resistivity technique (used in this study) measures apparent resistivity of the ground to a maximum depth of $50 \mathrm{~m}$. The technique is able to locate changes in weathered zone and differences in geology, and identify thickness of sand or gravel within superficial deposits. It is often used to calibrate EM surveys. It is how- 
ever a slow survey method and its data requires careful interpretation (MacDonald, Davies and Peart, 2001). Sandstone can easily be distinguished from mudstone using the resistivity method (Davies and MacDonald, 1999; Interconsult, 1985). Similarly, harder mudstones can also be distinguished from soft mudstone. In areas where large sandstone or limestone aquifers are present, as in the TolonKumbungu district, little or no detailed siting is required for rural domestic supply; boreholes can be drilled anywhere. This thus makes the resistivity survey method suitable for the study area.

In this study, fifteen sites in two communities in the Tolon-Kumbungu district were prospectively explored in order to site boreholes. Exploration sites were studied using the dipoledipole configuration for vertical electrical sounding (VES) in order to reveal prospects for groundwater and subsequent drilling of the sites; the goal was to assess the effectiveness of VES for well siting in the study area. In addition to the prospective data, retrospective VES data for six other sites were included in this study to enhance reliability of the deductions. The geophysical data gathered (using the VES technique) and their corresponding drill/well logs, where available, were compared in order to establish correlations with groundwater prospects at the exploration sites.

\section{MATERIALS AND METHODS \\ Study Area}

This study was carried out in the TolonKumbungu district, which lies in the Voltaian Sedimentary Basin with a range of topography of about $120 \mathrm{~m}$ to $180 \mathrm{~m}$ above sea level (Tolon-Kumbungu District Assembly, 2006). The District lies between latitudes $9^{\circ} 17^{\prime} \mathrm{N}$ and $10^{\circ} 06^{\prime} \mathrm{N}$, and longitudes $0^{\circ} 55^{\prime} \mathrm{W}$ and $1^{\circ} 21^{\prime} \mathrm{W}$ (Cobbina et al., 2012), and shares borders with the West Mamprusi District in the North, West Gonja District in the West, Savelugu/Nanton District in the East, and the Tamale Metropolitan area in the Southeast.

The soil type of the area is generally of the sandy loam type except in the low lands where alluvial deposits and gravel are found (Ghana Statistical Service, 2014). In addition, upper voltaian sandstone and quartzite underlie a small portion of the district at the extreme northwest (Cobbina et al., 2012). The sandstones are mostly impermeable but where extensive fractures occur, considerable water might be collected into the regolith to form groundwater reservoirs. It is reported that groundwater supplies in the area are mainly from the weathered layers or regolith developed on the rocks, and fractures within the bedrock (Gill, 1969). The aquifers are often discontinuous in nature (Cobbina et al., 2012), while the occurrence of lateritic cover in some areas are often associated with poor groundwater reserves.

The rock types in the Voltaian Sedimentary Basin include fine-grained sandstone, mudstone, shale, siltstone and intercalations of these rocks at some places. These rocks mostly become permeable through jointing, fracturing and weathering. The predominant bedrock in the area however is shale, with the various rocks having varying groundwater potential, influenced by the climate and geology of the area (Tolon-Kumbungu District Assembly, 2006).

The ideal locations for wells in the Voltaian district are in faults and fracture zones in sedimentary rocks (including sandstone, mudstone, and shale) that are overlain by a groundwater saturated weathered zone through which the fault or fracture zone is being recharged. This therefore makes the VES method suitable for the study area, as it is effective at detecting faults or fracture zones.

\section{Geophysical survey}

Vertical Electrical Sounding (VES) as an Electrical Resistivity Survey technique was used to locate suitable subsurface electrical conditions by exploiting the resistivity contrast between fresh unproductive rock and water-bearing zones. The resistivity of the former commonly exceeds $1500 \Omega \mathrm{m}$, whereas that of the waterbearing zones is lower, being dependent upon the degree of weathering and the groundwater quality (McNeil, 1980). Variation of resistivity with depth was therefore explored using the VES technique. The depth of investigation for the VES survey at all the stations started from 
$8.0 \mathrm{~m}$, as the water table in the district is reported to be between the depths of $9.0 \mathrm{~m}$ and 10.5 $\mathrm{m}$ (Bayor, 2004). The maximum investigation depth was $60.0 \mathrm{~m}$

The survey process involved passing low frequency alternating current into the ground through two metal current electrodes and measuring the resulting potential difference across two potential electrodes. By maintaining a known distance of separation between the four electrodes, a resistivity value for that location of the Earth can be calculated (Eqn. 1). Increasing the distance between the electrodes effectively increases the depth of penetration of the sounding. Thus, deviations from the pattern of potential differences expected from a homogeneous ground provide information on the form and electrical properties of the subsurface inhomogeneities.

By knowing the expected resistivity of the rock encountered (Table 1), anomalies can be investigated to infer the presence of groundwater. Importantly, higher apparent resistivity values are indicative of drier subsurface structures that do not show promise for moisture or water presence (a condition that would rather increase electrical conductivity). The focus therefore is on lower apparent resistivity values that may point to weathered, wet or water-bearing subsurface structures.

The dipole-dipole configuration (Fig. 1) for
VES was used in the exploration process. In this configuration, the current electrodes $\mathrm{A}$ and $\mathrm{B}$ and the potential electrodes C and D are separated, each pair having a constant mutual separation, $\mathbf{a}(\mathrm{m})$. If the distance $\mathbf{L}(\mathrm{m})$ between the two pairs is relatively large, i.e. $(\mathbf{L}>>\mathbf{a})$, each pair may be treated as an electric dipole of resistivity, $\rho(\Omega \mathrm{m})$ evaluated as (Bayor, 2004):

$$
\rho=\frac{2 \pi V\left[L\left(L^{2}-a^{2}\right)\right]}{I a^{2}}
$$

where $\mathrm{V}$ is potential difference $(\mathrm{V})$, I is current (A) and $\pi$ is a constant (3.142).

The dipole-dipole configuration (Fig. 1) is advantageous for VES surveys because the current and potential dipole cables are well separated from one another, which effectively reduces noise due to electromagnetic inductive coupling (Sharma, 1997). Thus, due to the noise-prone nature of the Voltaian Sedimentary Basin (Bayor, 2004), as it is in the TolonKumbungu district, the dipole-dipole configuration is most appropriate for the VES survey. However, one limitation of the VES survey technique is that the power supplied to the ground reduces in magnitude or penetration ability with the depth of investigation (McNeil, 1980). This is mostly influenced by the stren-

Table 1: Apparent resistivity values for some common rocks

\begin{tabular}{ll}
\hline Rock material & Resistivity range $(\mathbf{\Omega m})$ \\
\hline Limestone (marble) & $>10^{12}$ \\
Quartzitic rock & $10^{10}-10^{12}$ \\
Rock salt & $10^{6}-10^{7}$ \\
Granite & $5000-10^{6}$ \\
Sandstone & $35-4000$ \\
Limestone & $120-400$ \\
Clay/Shale/Mudstone & $1-20$ \\
\hline
\end{tabular}

(Source: Bayor, 2004) 


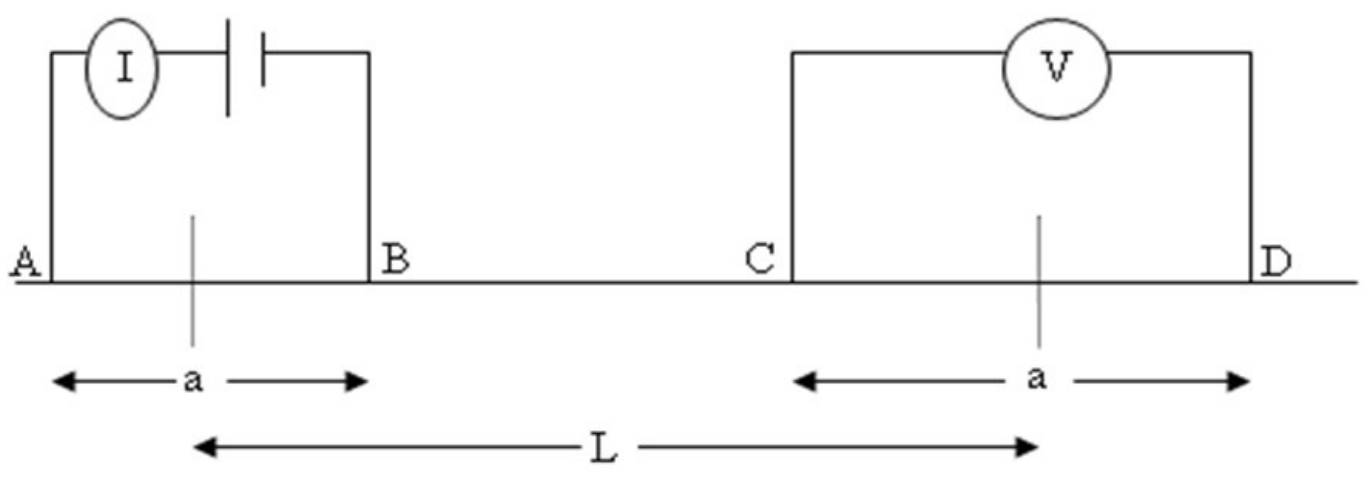

Fig. 1: The dipole-dipole configuration for VES survey

gth of the power supply and the conductivity of the medium. The SAS-300 C terrameter (ABEM, Sweden) was used for the VES surveys at the exploration sites.

\section{Fieldwork}

Using an exploration station as the central point of the configuration, the potential and current electrodes were continuously expanded about the station while maintaining a constant current. For a given electrode spacing, log-log curves plotted as apparent resistivity $(\Omega \mathrm{m})$ versus depth $(\mathrm{m})$ along a given traverse were generated for each exploration station, to qualitatively interpret subsurface anomalies. Interpretation of the curves involved using the apparent resistivity values recorded as means of identifying expected rock materials (Table 1) such that deviations from these resistivity patterns could be related to the possible presence of an aquifer.

\section{Selection of survey and drill sites}

Preliminary observation of the study sites was made, and areas that were visibly sloping in nature were considered for electromagnetic (EM) survey. EM survey was carried out to observe anomalies that gave indication of groundwater holding potential. Resistivity survey was then conducted across identified anomalies at selected sites. Fifteen sites were selected in two study communities for VES profiling, using the EM profiles of those sites. The selected study sites were mostly randomly distributed. Sites were recommended for drilling if the analysis of their respective log-log VES curves showed greater prospects of holding groundwater. Even though 8 out of 15 sites were recommended for drilling, only 3 sites were drilled during the period of this study; therefore, only these three sites had corresponding drill logs to validate the log-log VES curve analysis. Secondary VES data and their corresponding drill logs for six other communities were therefore obtained retrospectively from the World Vision International Water Project in the study area to complement the prospective data from this study. The six communities were Gbanjong, Song, Zoonayili, Gbanzogu, Sindigu, and Kanshegu.

\section{RESULTS \\ Dipole-Dipole VES surveys \\ Gbullung geophysical survey}

Table 2 shows the apparent resistivity values recorded at the six stations surveyed in Gbullung.

The resistivity values at station G1 (Table 2) can be interpreted to indicate a dry sandy overburden at the top, underlain by plastic clay sediments as shown by the resistivity 
Table 2: Dipole-dipole VES survey results for the Gbullung community

\begin{tabular}{lllllll}
\hline Depth (m) & \multicolumn{5}{c}{ Apparent resistivity at station $(\mathbf{\Omega m})$} \\
\hline & $G 1^{*}$ & $G 2$ & $G 3$ & $G 4$ & $G 5$ & $G 6$ \\
8.0 & 57.8 & 43.8 & 42.0 & 36.7 & 39.4 & 54.2 \\
12.0 & 33.8 & 44.7 & 33.4 & 23.8 & 46.5 & 41.7 \\
16.0 & 30.4 & 41.9 & 33.6 & 29.3 & 50.5 & 45.8 \\
20.0 & 42.1 & 36.6 & 32.6 & 26.9 & 49.1 & 44.3 \\
25.0 & 34.5 & 38.5 & 26.5 & 30.2 & 41.2 & 42.9 \\
30.0 & 31.7 & 48.6 & 22.4 & 29.2 & 47.7 & 44.9 \\
35.0 & 40.1 & 48.0 & 32.1 & 27.4 & 52.6 & 50.4 \\
40.0 & 50.2 & 38.6 & 38.5 & 31.7 & 44.3 & 54.2 \\
45.0 & 45.6 & 40.6 & 32.2 & 27.2 & 45.2 & 54.4 \\
50.0 & 50.8 & 52.0 & 33.4 & 27.1 & 50.8 & 62.8 \\
60.0 & 60.1 & 55.4 & 44.9 & 30.4 & 79.2 & 81.8 \\
\hline
\end{tabular}

*Drilled station

values dropping initially from $57.8 \Omega \mathrm{m}$ to 33.8 $\Omega \mathrm{m}$. This gradient variation is probably due to the hard nature of some of the components of the overlying material, which is expected to be hard sandstone. The inflexion points at $20.0 \mathrm{~m}$ and $30.0 \mathrm{~m}$ may point to some prospects of groundwater presence, and of hard rock areas. Below $35.0 \mathrm{~m}$, there does not seem to be good prospects of groundwater presence; the site however generally appears to hold some potential of groundwater presence, likely to be encountered at the depths of $20.0 \mathrm{~m}$ to $30.0 \mathrm{~m}$.

\section{Wayamba geophysical survey}

Table 3 shows the apparent resistivity values recorded at the nine stations surveyed in Wayamba.

At station W3 (Table 3), the very high initial resistivity of $774.5 \Omega \mathrm{m}$ is indicative of a dry, hard rock formation. A sharp drop in resistivity then is observed from the depth of $12.0 \mathrm{~m}$ to that of $30.0 \mathrm{~m}$. This drop is suggestive of a predominantly shale environment and the likelihood of a major aquifer. The resistivity values then remain fairly constant between the depths of $35.0 \mathrm{~m}$ and $50.0 \mathrm{~m}$ and finally drop slightly from the depth of $50.0 \mathrm{~m}$ to $60.0 \mathrm{~m}$; this indicates a uniform lithology (from $35.0 \mathrm{~m}$ to $60.0 \mathrm{~m}$ ). The $35.0 \mathrm{~m}$ depth therefore marks the end of the major aquifer region, from where a shale formation is likely to be present. Generally, station W3 appears to be a more promising location of groundwater over a 15.0 $\mathrm{m}$ stretch (from a depth of $20.0 \mathrm{~m}$ to $35.0 \mathrm{~m}$ ), where the water table will most likely be encountered within the depths of $12.0 \mathrm{~m}$ to 20.0 $\mathrm{m}$.

The resistivity values for station W5 (Table 3) indicate the possibility of a hard rock overburden, most likely to be underlain by shale. A highly conductive layer is expected below the $12.0 \mathrm{~m}$ depth. Between the depths of $25.0 \mathrm{~m}$ and $40.0 \mathrm{~m}$, a continuous decline in the resistivity values is observed. The $25.0 \mathrm{~m}$ to 40.0 $\mathrm{m}$ depth range shows prospect for groundwater presence or at least a weathered shale zone (if there is no groundwater present); this zone may be sandwiched between a mudstonesandstone intercalation or shale above (within the $12.0 \mathrm{~m}$ to $20.0 \mathrm{~m}$ depth range) and a dry hard rock or sandstone formation below (within the $45.0 \mathrm{~m}$ to $60.0 \mathrm{~m}$ depth range). The $25.0 \mathrm{~m}$ to $40.0 \mathrm{~m}$ depth range is generally promising for groundwater presence.

Retrospective geophysical survey results for six communities

Resistivity values at the Gbanjong community 
Dipole-dipole VES technique in groundwater prospecting ... 49

Table 3: Dipole-dipole VES survey results for the Wayamba Community

\begin{tabular}{|c|c|c|c|c|c|c|c|c|c|}
\hline \multirow[t]{2}{*}{ Depth (m) } & \multicolumn{9}{|c|}{ Apparent resistivity at station $(\Omega m)$} \\
\hline & $W 1$ & $W 2$ & $W 3 *$ & W4 & $W 5^{*}$ & W6 & $W 7$ & $W 8$ & W9 \\
\hline 8.0 & 74.6 & 138.6 & 774.5 & 374.8 & 143.1 & 34.7 & 72.4 & 107.1 & 34.5 \\
\hline 12.0 & 25.6 & 62.6 & 551.6 & 23.2 & 26.7 & 118.5 & 56.5 & 203.2 & 17.2 \\
\hline 16.0 & 33.6 & 49.4 & 120.4 & 38.0 & 63.3 & 44.3 & 78.5 & 35.5 & 38.0 \\
\hline 20.0 & 31.5 & 49.8 & 59.4 & 47.5 & 41.5 & 24.5 & 72.6 & 41.5 & 72.6 \\
\hline 25.0 & 29.4 & 50.9 & 40.3 & 35.4 & 75.4 & 22.6 & 91.6 & 80.3 & 37.7 \\
\hline 30.0 & 27.7 & 42.2 & 34.3 & 32.3 & 71.3 & 39.5 & 53.5 & 105.6 & 65.9 \\
\hline 35.0 & 31.7 & 42.2 & 52.8 & 43.3 & 68.6 & 42.2 & 73.9 & 141.5 & 105.6 \\
\hline 40.0 & 39.6 & 44.3 & 50.7 & 52.3 & 47.5 & 55.4 & 110.8 & 93.4 & 31.7 \\
\hline 45.0 & 45.2 & 45.2 & 52.0 & 52.0 & 67.9 & 67.9 & 158.4 & 92.8 & 73.2 \\
\hline 50.0 & 30.2 & 37.7 & 51.3 & 45.2 & 150.8 & 150.8 & 90.5 & 150.8 & 60.0 \\
\hline 60.0 & 37.0 & 26.4 & 38.3 & 48.8 & 263.9 & 152.3 & 131.9 & 79.2 & 62.2 \\
\hline
\end{tabular}

*Drilled station

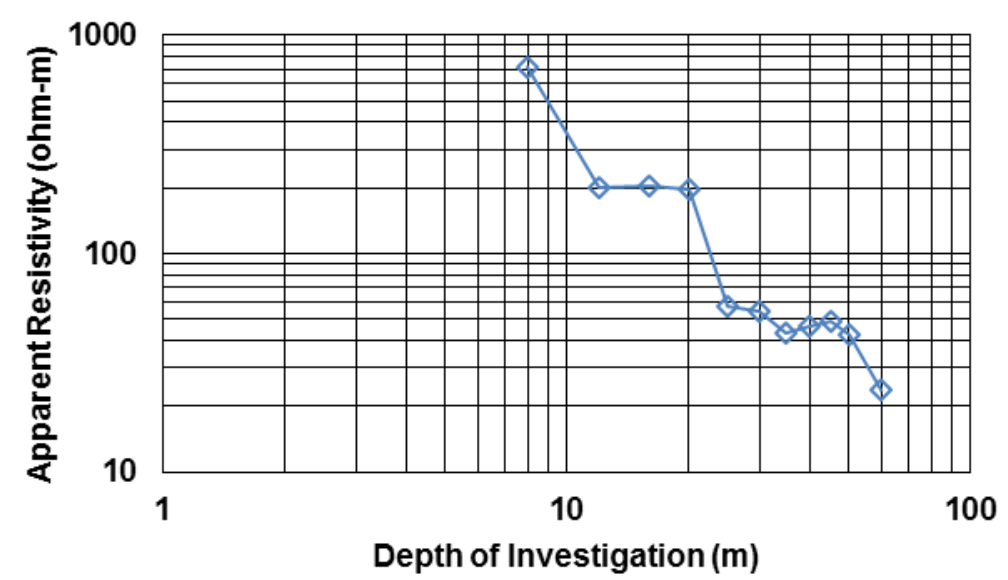

Fig 2: Log-log VES Curve for Gbanjong

(Fig. 2) varied between $23.6 \Omega \mathrm{m}$ and $712.3 \Omega \mathrm{m}$ (range of $688.7 \Omega \mathrm{m}$ ), representing a likely sandstone-dominant site. The very high resistivity of $712.3 \Omega \mathrm{m}$ shows a likely hard rock formation such as laterite. The Song community (Fig.3) had a resistivity range of $28.7 \Omega \mathrm{m}$ (from
$33.6 \Omega \mathrm{m}$ to $62.3 \Omega \mathrm{m})$. These low resistivity values are mostly associated with either one, or a mixture, of clay, shale and mudstone formations (Table 1). The Zoonayili site (Fig. 4) also had low resistivity values of between 24.5 $\Omega \mathrm{m}$ and $48.2 \Omega \mathrm{m}$ which also point to either 


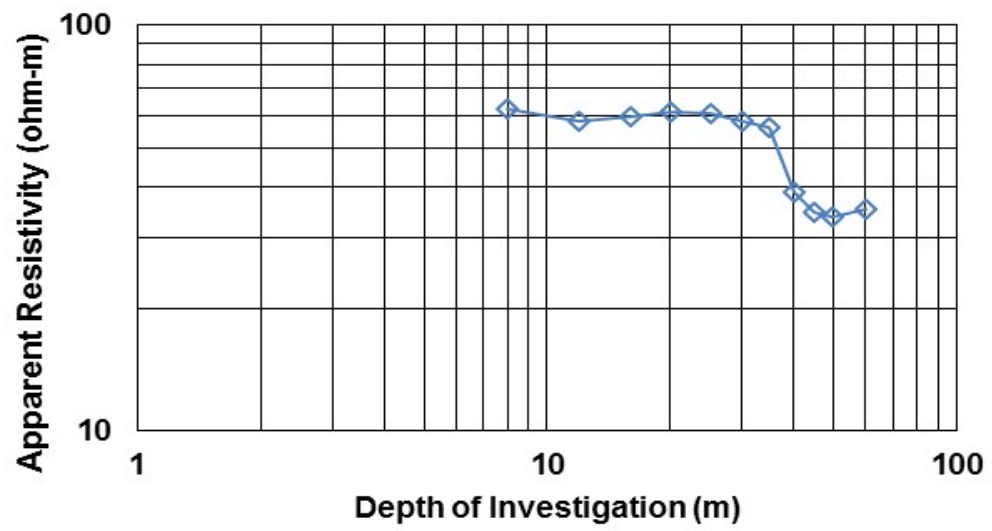

Fig 3: Log-log VES Curve for Song

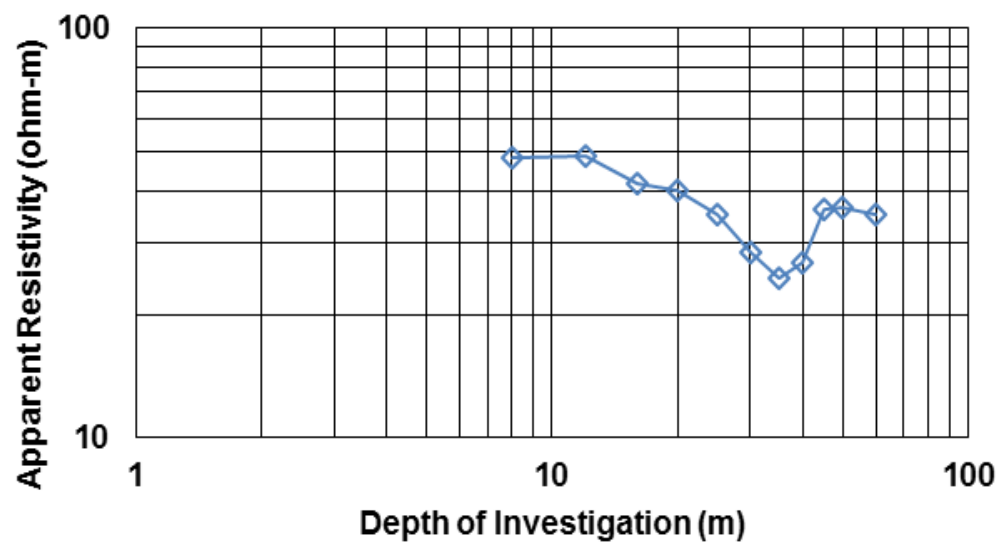

Fig 4: Log-log VES Curve for Zoonayili

one, or a mixture, of clay, shale and mudstone formations. The Gbanzogu, Sindigu and Kanshegu communities (Figs. 5-7) had resistivity value ranges of $56.4 \Omega \mathrm{m}, 589.2 \Omega \mathrm{m}$ and 47.2 $\Omega \mathrm{m}$, respectively. Their resistivity values are largely indicative of sandstone formations, with a likely lateritic top layer at Sindigu, where a very high resistivity value $(614.8 \Omega \mathrm{m})$ was recorded at a depth of $8.0 \mathrm{~m}$. 


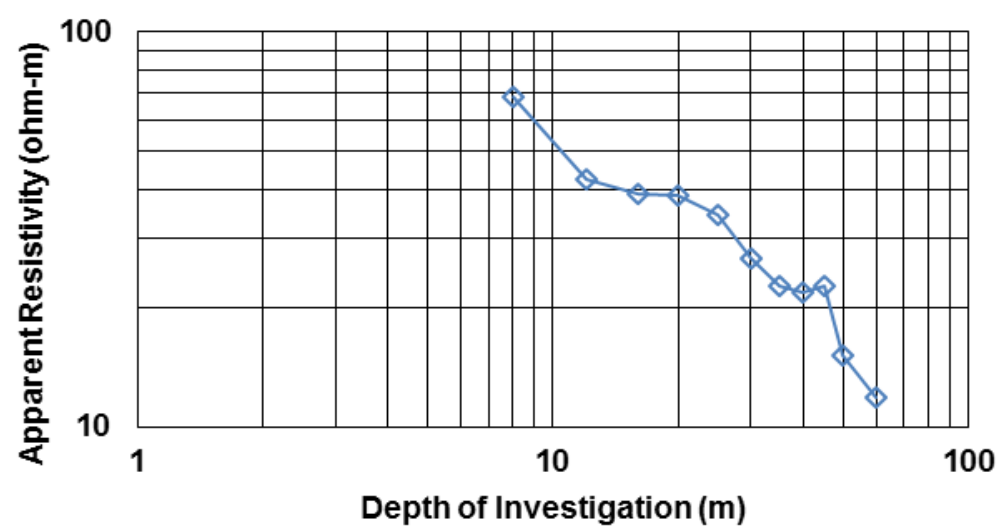

Fig 5: Log-log VES Curve for Gbanzogu

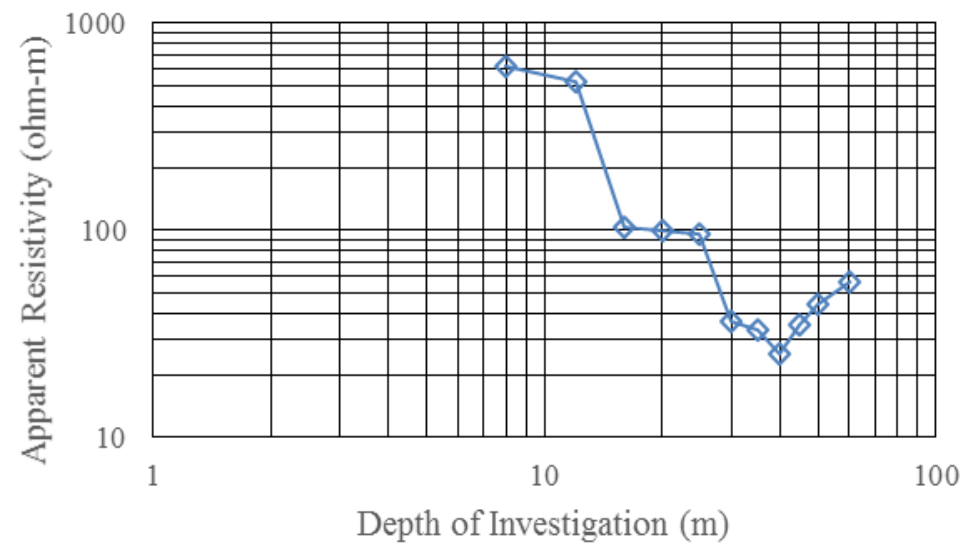

Fig 6: Log-log VES Curve for Sindigu

Prediction of depth range to expect groundwater

Using the VES data gathered at all the 21 stations surveyed in the 8 communities, an approximate depth range within which an aquifer could be encountered was predicted (Table 4).

The depth range within which groundwater is expected to be confined was determined by calculating the averages of the lower and upper analytical depth ranges shown in Table 4. Each average was estimated as the sum of the analytical depths divided by the number of stations surveyed (which was 21 for both the upper and lower analytical depths). The average ( \pm standard deviation) lower depth limit was found to 


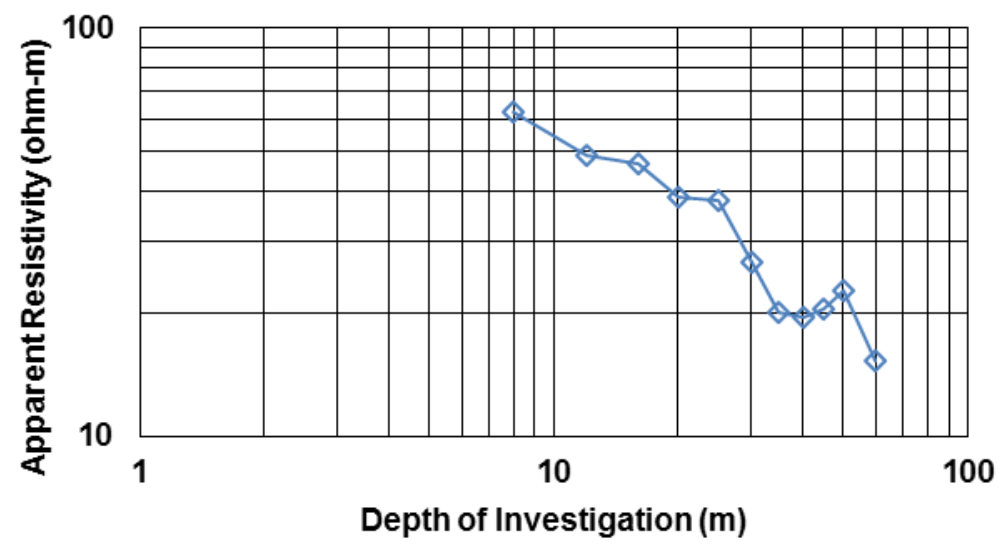

Fig 7: Log-log VES Curve for Kanshegu

Table 4: Expected depth range of groundwater prospects at the various survey stations

\begin{tabular}{lcc}
\hline Community & Station label & $\begin{array}{l}\text { Analytical depth range of groundwater } \\
\text { prospect (m) }\end{array}$ \\
\hline Gbullung & G1 & $20.0-35.0$ \\
& G2 & $35.0-40.0$ \\
G3 & $40.0-50.0$ \\
G4 & $25.0-40.0$ \\
G5 & $35.0-50.0$ \\
Wayamba & G6 & $20.0-25.0$ \\
& W1 & $16.0-30.0$ \\
W2 & $12.0-35.0$ \\
W3 & $20.0-35.0$ \\
W4 & $20.0-30.0$ \\
W5 & $25.0-40.0$ \\
W6 & $16.0-25.0$ \\
W7 & $25.0-30.0$ \\
Gbanjong & W8 & $35.0-45.0$ \\
Song & W9 & $35.0-40.0$ \\
Zoonayili & - & $20.0-45.0$ \\
Gbanzogu & - & $35.0-60.0$ \\
Sindigu & - & $20.0-45.0$ \\
Kanshegu & - & $25.0-45.0$ \\
\hline
\end{tabular}


be approximately $25.2(7.8) \mathrm{m}$, and the average ( \pm standard deviation) upper depth limit was about 40.2 (9.3) $\mathrm{m}$. Beyond this depth of 40.2 (9.3) $\mathrm{m}$, a very low possibility of locating groundwater is expected.

\section{Drill logs}

These were recordings of various formations encountered at stations G1, W3, W5, Gbanjong, Song, Zoonayili, Gbanzogu, Sindigu, and Kanshegu while drilling was carried out. Tables 5, 6 and 7 give the details of the soil/rock formations encountered from the surface down to the depth at which drilling was discontinued at each study site.

\section{DISCUSSION}

Interpretation of the VES results suggested that the survey area is predominantly an environment of sandstone, shale, mudstone or intercalations of these. The study further predicted groundwater presence within a $25.0 \mathrm{~m}$ to 40.0 $\mathrm{m}$ depth range. Borehole depths in the study area are reported (Cobbina et al., 2012) to range between $25.0 \mathrm{~m}$ and $96.0 \mathrm{~m}$, with an average depth of $43.0 \mathrm{~m}$. The upper limit of $25.0 \mathrm{~m}$ depth found in this study agrees with that of Cobbina et al (2012); however, there was very little possibility of locating water beyond 60.0 $\mathrm{m}$ at all sites surveyed in this study.

According to the drill logs (Tables 5, 6 and 7), surface layer thickness was $12.0 \mathrm{~m}$ on the average with varying compositions ranging from extremely weathered clay through highlymoderately weathered sandstone to the lateritic hard pan in increasing order of resistivity. The well logs further revealed that yields obtained in fractured mudstones were lower as compared to those in fractured, pure sandstone formations. Hard, fresh mudstone or shale environments however contained no water at all. Furthermore, the pattern of groundwater presence in the study area is discontinuous (Darko et al., 2006), and so yields are reported (Cobbina et al., 2012) to vary widely from about $4.5 \mathrm{~L} / \mathrm{min}$ to $600 \mathrm{~L} / \mathrm{min}$ with an average yield reported to be $32.6 \mathrm{~L} / \mathrm{min}$. Yields in this study varied between $14 \mathrm{~L} / \mathrm{min}$ and $250 \mathrm{~L} / \mathrm{min}$, with an average yield of $87.3 \mathrm{~L} / \mathrm{min}$ (from 8 out of 9 successful wells drilled).
Information obtained from the VES results for station Gbullung G1 (Table 3) revealed the presence of a dry sandy overburden down to a depth of 12.0. Below this depth was a hard rock formation. The interpretation further predicted that the water-bearing zone at the station could be encountered between $20.0 \mathrm{~m}$ and $35.0 \mathrm{~m}$ deep. In fact, the drill log for the station confirmed this interpretation where a water-bearing zone was encountered within a $17.0 \mathrm{~m}$ to $34.0 \mathrm{~m}$ depth range, with a final flow rate of $68 \mathrm{~L} / \mathrm{min}$. Furthermore, a dry topsandy soil was encountered, and from $9.1 \mathrm{~m}$ down to the beginning of the water-bearing zone was a hard, fresh, slightly fractured sandstone formation. Therefore, this was an accurate curve interpretation and a successful borehole location.

The VES curve interpretation for station Wayamba W3 (Fig. 4) suggested a top-dry hard rock layer with a relatively higher apparent resistivity value. These resistivity values indeed compare with those of laterite due to its hard, cemented nature. The interpretation further provided a possible depth range of $20.0 \mathrm{~m}$ to $30.0 \mathrm{~m}$ within which groundwater was likely to be encountered. The well log confirmed this prediction when water was first encountered $20.0 \mathrm{~m}$ deep and about $33.0 \mathrm{~m}$ deep, it was advisable to discontinue drilling when a maximum flow rate of $105 \mathrm{~L} / \mathrm{min}$ was recorded. This was also an accurate VES curve interpretation and a successful well location.

According to the VES results for station Wayamba W5 (Table 3), the higher apparent resistivity at the top suggested a hard rock formation, which was confirmed by the well $\log$ when a laterite formation was encountered at the top. This was followed below by a less conductive $30.0 \mathrm{~m}$ thick layer of highlymoderately weathered shale. The interpretation further cited the possibility of a major aquifer or a fractured layer (or shale in the absence of a major aquifer) within a depth range of 25.0 $\mathrm{m}$ to $40.0 \mathrm{~m}$. However, no water was encountered within this zone. The highly conductive weathered shale environment at this station could have accounted for this inaccuracy in predicting groundwater presence. Shale is nonpermeable and so groundwater potential in 


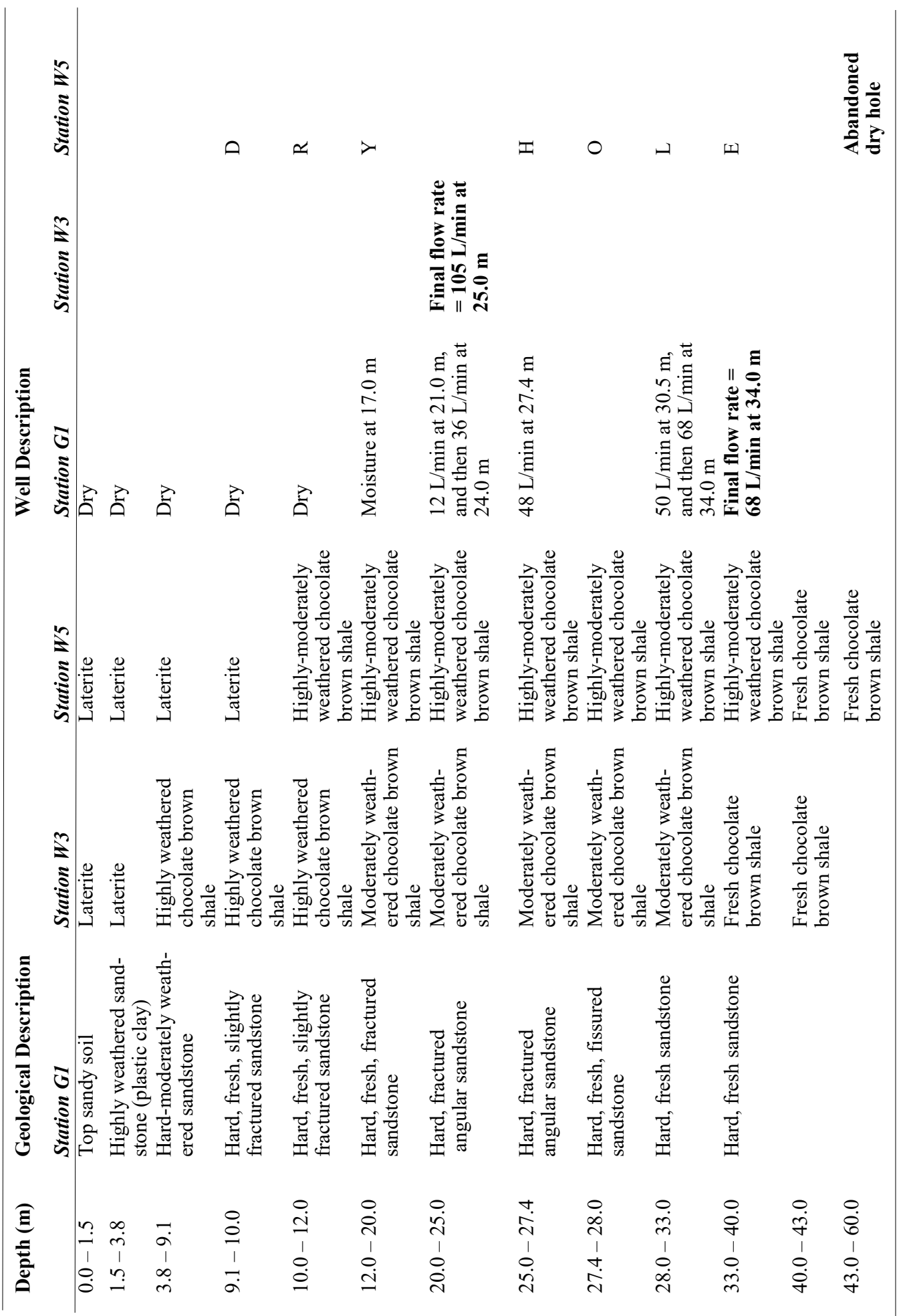




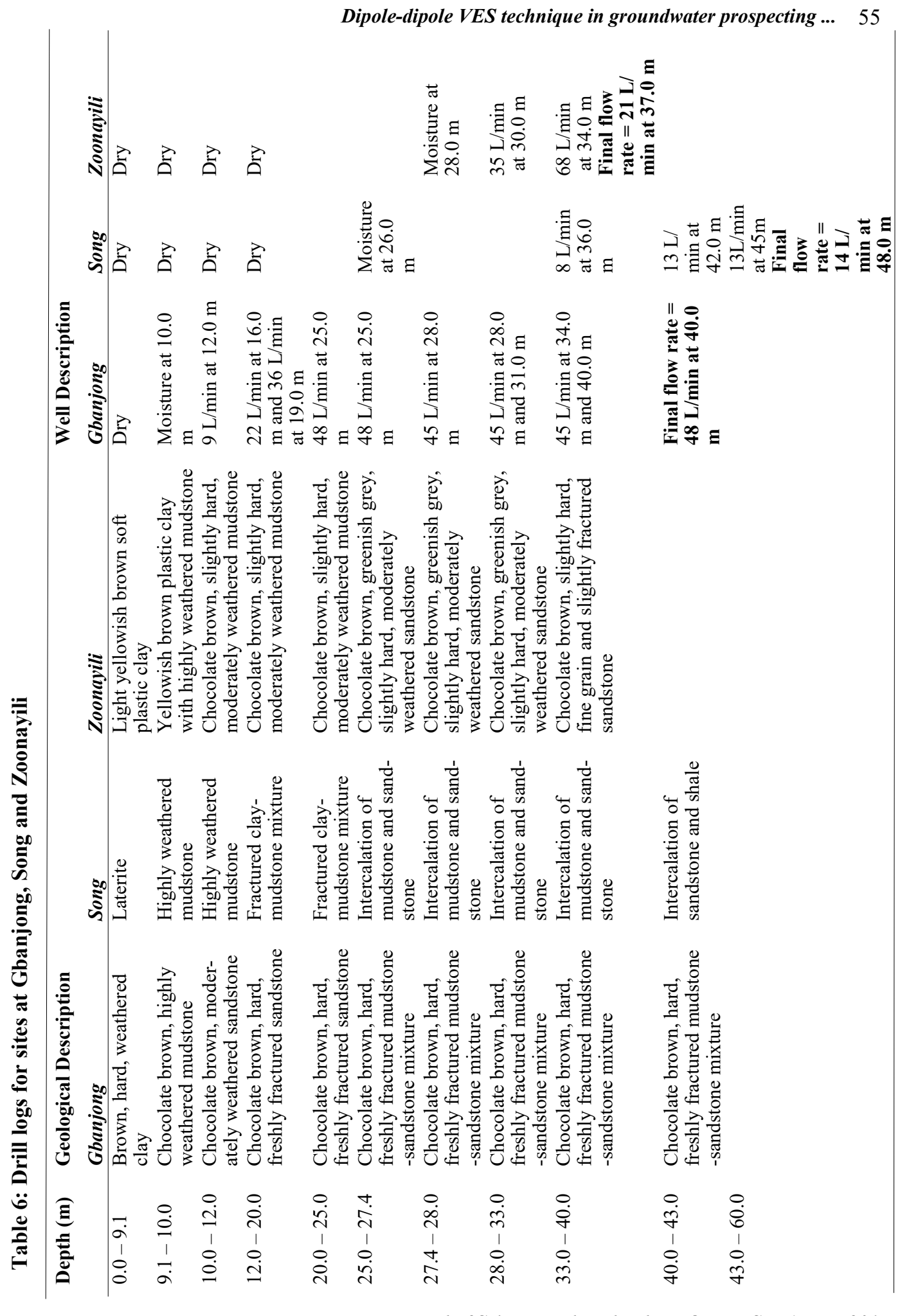

Journal of Science and Technology @ KNUST August 2017 


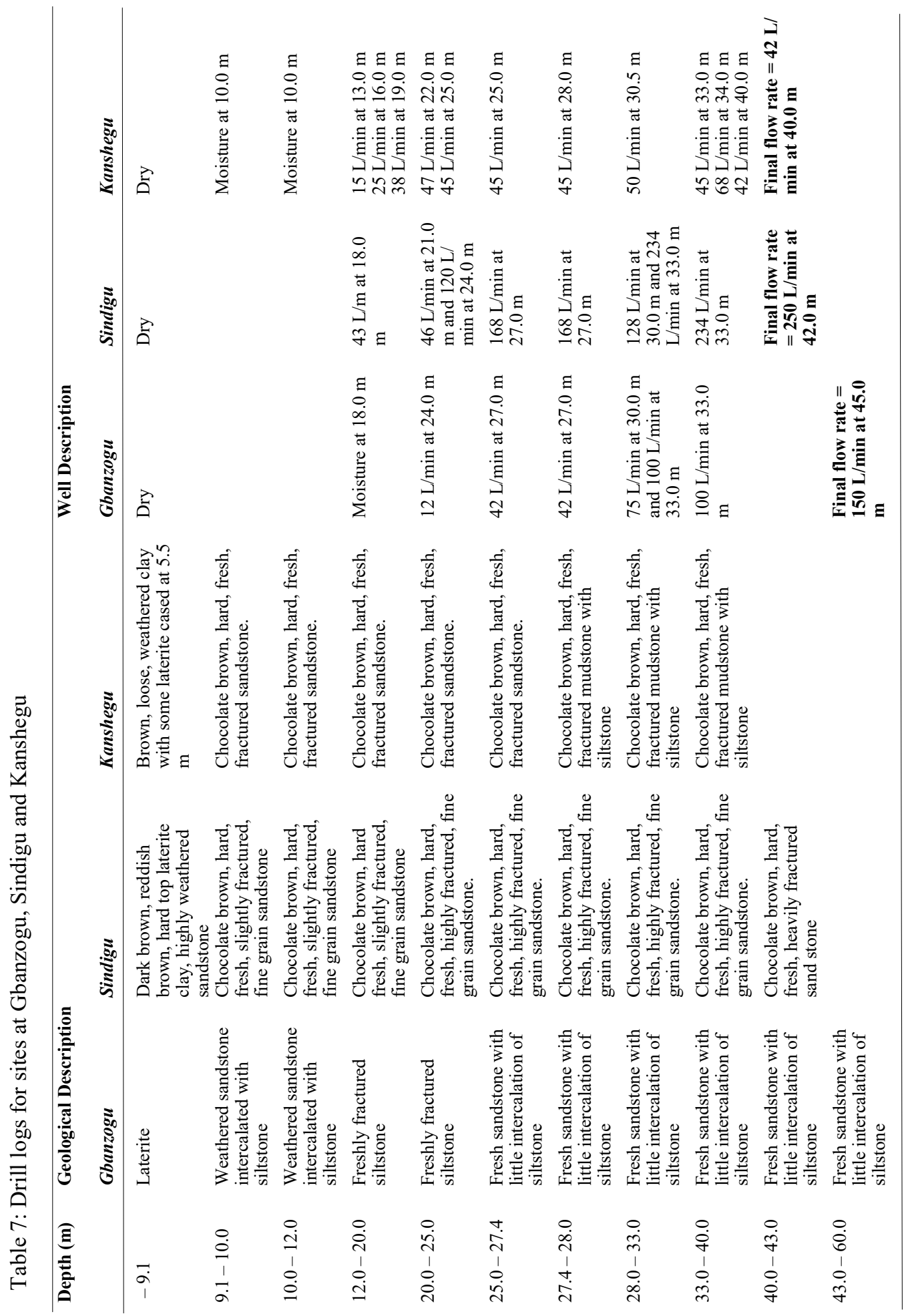


such an environment does not generally offer a good yield. Consequently, this was a good curve interpretation for an unfavorable well.

The retrospective data also showed agreements between the log-log VES curve analysis (Figs. $2-7)$ and their corresponding well logs (Tables 6 and 7), as has been discussed for the prospective data in the preceding paragraphs. The findings of this study thus show that the dipoledipole configuration for VES survey is accurate at predicting groundwater presence or at least subsurface structures that show promise for holding groundwater. However, the apparent resistivity values alone appear to lack the sensitivity to discriminate between weathered or moist formations that do not necessarily confine water, and actual aquifers. Future studies should therefore consider sensitivity improvements of the technique, or enhancing its accuracy by complementing it with other suitable but cheap techniques.

\section{CONCLUSION}

The agreement between the VES results/curve interpretations and their corresponding well logs indicated that the dipole-dipole method in resistivity surveying is appropriate for the geology of the study area. Using the technique, the various rock types ranging from thin sandstone to thick mudstone and shale were clearly differentiated. Furthermore, the approximate depth within which a major water zone could be encountered was established. For a low-cost and effective geophysical survey, the dipole-dipole VES method may therefore be the recommended means of locating fractured sandstone formations, and studying the vertical composition and aquifer condition of the subsurface.

\section{ACKNOWLEDGEMENT}

The authors wish to acknowledge funding support for the Rural Water Supply and Sanitation Project by the French Development Agency (AFD), under which this study was carried out. The authors wish to acknowledge the permission and support of Terrahydro Associates Limited (TAL) in Tamale offered us to undertake this study with their Geophysicists at the study sites. The provision of the drill logs by TAL to enable us conduct the geophysical analysis and validation is also appreciated. Sincere thanks also go to Mr. Francis Okai of World Vision International for the provision of the retrospective VES data for inclusion in this paper.

\section{REFERENCES}

Bayor, J. S. (2004). “Application of the electromagnetic and the electrical resistivity methods in groundwater exploration in the TolonKumbungu district of the Northern Region of Ghana." M.Sc. Thesis, Kwame Nkrumah University of Science and Technology, Kumasi.

Cobbina, S. J., Armah, F. A., and Obiri, S. (2012). "Multivariate statistical and spatial assessment of groundwater quality in the Tolon-Kumbungu District, Ghana." Research Journal of Environmental and Earth Sciences, 4(1), 88-98.

Dapaah-Siakwan, S. and Gyau-Boakye, P. (1999). "Groundwater resources of Ghana". In: "Advances in groundwater exploration and development in Ghana." Proceedings of a seminar organized by the Department of Geology, University of Ghana, in collaboration with the Geological Institute, University of Copenhagen, under the auspices of DANIDA ENRECA Hydrogeological Project, October 22-23, 1999. GEODAT Resources. pp 53-72.

Darko, P. K., Mainoo, P. A. and DapaahSiakwan, S. (2006). "Borehole inventory, numbering and functionality survey in TolonKumbungu District." District Specific Preliminary Hydro Geological Report.

Davies, J. and MacDonald, A. M. (1999). "Final report: the groundwater potential of the Oju/Obi area, eastern Nigeria." British Geological Survey Technical report $\mathrm{WC} / 99 / 32$.

Falkenmark, M. and Rockström, J. (1993). "Looming water crisis; new approaches are inevitable." In: Ohlsson L. (Ed), Hydropolitics: conflicts over water as a development constraint." Zed Publishers, London.

Ghana Statistical Service (2014). "2010 Population and housing census : District Analytical Report ." Tolon District. Pp 3 
Gill, H. E. (1969). "A groundwater reconnaissance of the Republic of Ghana, with a description of geohydrologic provinces." Geological Survey Water-Supply Paper 1757-K, Washington.

Interconsult (1985). "National Master Plan for Rural Water Supply and Sanitation. Volume 2/2. Hydrogeology." Prepared for the Ministry of Energy and Water Resources and Development, Republic of Zimbabwe.

MacDonald, A. M. and Davies, J. (2000). "A brief review of groundwater for rural water supply in sub-Saharan Africa." BGS Technical Report WC/00/33.

MacDonald, A. M., Davies, J., and Peart, R. J. (2001). "Geophysical methods for locating groundwater in low permeability sedimentary rocks: examples from southeast Nigeria." Journal of African Earth Sciences, 32: 1-17.

McNeil, J. D. (1980). "Electromagnetic terrain conductivity measurement at low induction numbers." GEONICS Ltd., Canada.

Sharma, P. V. (1997). "Environmental and En- gineering Geophysics." Cambridge University Press, United Kingdom.

Tolon-Kumbungu District Assembly. (2006). "Profile of the Tolon-Kumbungu District of Ghana." Northern Region, Ghana.

United Nations Development Programme, UNDP. (1994). "World Bank water and sanitation program." International Bank for Reconstruction and Development/The World Bank, 1818H Street, NW Washington DC, 20433 USA.

Wicander, R., and Monroe, J. S. (1995). "Essentials of Geology." USA: West Publishing Company.

World Bank (1993). "Water resources management." A World Bank policy paper, Washington DC, USA.

World Health Organization and UNICEF (2012). "Progress on Drinking Water and Sanitation: 2012 Update." United States: WHO/UNICEF Joint Monitoring Programme for Water Supply and Sanitation. 